\title{
Editor's Introduction: Constructionism as Interpretive Tradition and as Emergent Deviance in Sociology
}

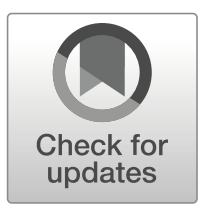

\author{
Lawrence T. Nichols ${ }^{1}$
}

Published online: 18 May 2019

(C) Springer Science+Business Media, LLC, part of Springer Nature 2019

In this issue we present a rich and diverse set of articles about social constructionism as a recent intellectual movement in sociology, including an assessment of its strengths and weaknesses and some consideration of its future prospects. The issue thus exemplifies again the distinctive mission of The American Sociologist to consider the past, present and future of sociology as an organized field of study. Earlier issues of the journal looked at such related topics as the humanist movement and the debate over the alleged "death" of the sociology of deviance. It would be interesting also to consider the fluctuations of popularity and influence of various subfields of sociology, such as social psychology and the community studies tradition.

Special thanks are due to Professor Michael Adorjan, who did the most to organize this set of papers and to see the project through from start to finish. Thanks also to all the authors who contributed. Professor Adorjan has commented on the individual articles in his Guest Editor's Introduction, which I will supplement here with more general considerations.

The most interesting issue, in my view, is the dual status of Constructionism in the contemporary field of sociology, especially within the United States, as both a legitimate and valuable expression of the well-established tradition of interpretive sociology and also as an emergent form of deviance as assessed from the increasingly hegemonic conflict perspective. There is, in other words, a largely polarized response to Constructionism, and those who work within the constructionist frame find themselves increasingly on the defensive, not only intellectually, but more importantly, in a moral sense as well. For critics of Constructionism often view it as not only intellectually inadequate but also as ethically compromised or even ethically evil insofar as it supports or fails to resist what critics regard as obvious oppression and human suffering.

From an historical perspective, Constructionism may be said to have deep roots in the interpretive tradition that flourished in nineteenth and early twentieth-century Germany, where it was closely linked to Idealism in philosophy and also to

Lawrence T. Nichols

lnichol2@wvu.edu

1 West Virginia University, Morgantown, WV, USA 
historiography. In the work of Karl Marx, the interpretive emphasis appears in the notion of "consciousness" as well as "ideology." Max Weber extended the approach through his analysis of the "spirit" (geist) of capitalism and through his methodology of ideal types. W. E. B. DuBois, following a period of study in Germany, famously wrote of the "souls" of black folks - a term that does not appear in the writings of other founding figures such as Spencer and Durkheim. The emphasis in these examples was on interiority and the operation of mind as the basis of knowledge.

Overlapping these developments chronologically, American pragmatists - most famously Charles Peirce, William James, John Dewey and George Herbert Meadfocused on the creation of meaning through human agency. The two streams converged in what became known as Symbolic Interactionism, in which the idea of the human "self" was central, a concept also closely related to the idea of "mind" and its "internal conversation," as well as communication within human groups via significant symbols. Herbert Blumer, who studied with Mead at Chicago, coined the term "symbolic interaction" in 1937 in a survey of approaches to social psychology.

In the 1950s and 1960s, Edwin Lemert, Howard S. Becker, Erving Goffman and others combined some of these ideas in the widely influential Labeling theory of crime and deviance. Operating within this frame, sociologists examined how particular behaviors came to be defined as deviant or criminal, and how individuals acquired corresponding identities, especially through the imposition of labels, often arbitrarily, by official agencies, both secular and religious. The creation of deviant or criminal selves, it was thought, often led to careers of norm-breaking, especially when selflabeling occurred.

Constructionism appeared as a distinctive project in the late 1970s, following the publication of the programmatic work, Constructing Social Problems by Malcolm Spector and John Kitsuse. Carrying over the logic of labeling theory, these authors asserted that symbolic objects called "social problems" were simply "putative conditions" that had been labeled as problems by means of "claims-making activities" of those who defined them.

Insofar as Constructionism focused on meaning-making through communicative interaction, it was a symbolic interactionist project. But the Spector-Kitsuse treatise also reflected the influence of the more radical epistemology of ethnomethodology, especially as formulated in the works of Harold Garfinkel, and his 1967 book, Studies in Ethnomethodology in particular. From this perspective, it connected also with the phenomenological approach presented by Peter Berger and Thomas Luckmann in The Social Construction of Reality. Like German Idealism, and the idealistic tradition more generally, Constructionism - in its "strong" or "strict" reading - problematized naïve understandings of a material world.

Meanwhile, in what might be regarded as a dialectical manner, the field of sociology in the U.S. and in Europe began to move in a different direction, based on materialist and conflict assumptions. Early indications of the shift appeared in C. Wright Mills's critique of The Power Elite, as well as in a new literature on elites and what came to be called "political economy," among which G. William Domhoff's study, Who Rules America? was especially significant. In roughly the same period, Ralf Dahrendorf published an influential critique of the functionalist approach entitled, "Out of Utopia."

Soon thereafter, a neo-Marxist movement emerged and gained many adherents, such as Richard Quinney who published The Social Reality of Crime and Critique of Legal 
Order. Meanwhile Michael Burawoy published Manufacturing Consent: Changes in the Labor Process under Monopoly Capitalism. Erik Olin Wright brought out Class, Crisis and the State. Immanuel Wallerstein published a series of works on "world systems theory," including The Capitalist World Economy. Others, such as Jack Roach, advocated Radical Sociology, and an ethos of "insurgency," most explicitly embraced in the new journal, The Insurgent Sociologist, took root.

More recently, the conflict frame has taken the forms of feminism, including the "black feminism" of Patricia Hill Collins, as well as "queer theory" and "critical race theory." The key ideas of these various approaches, such as "intersectionality" and "color-blind racism," have converged in the approach of "liberation sociology" as advocated by Joe Feagin and Hernan Vera. Underlying all of them is an idea deeply rooted in German thought, and most famously articulated by Friedrich Nietzsche, namely, the "will to power." It is an article of faith that power, understood as domination, is the fundamental reality in the social world. Material forces and material interests drive the historical process. The Idealist notion of the search for truth and meaning - which, as noted above, underlies Constructionism-is therefore largely an illusion and an expression of false consciousness.

Gradually, in a manner that has yet to be documented fully, the conflict approach in its many variations or "fractals" (as Andrew Abbott might say) became increasingly hegemonic in the United States. Christian Smith recently interpreted these developments as the emergence of a "sacred project" in sociology around the struggle for "equality" that was understood not only as an ideal but also as a moral absolute. Sociology departments around the country began to define themselves in terms of "social justice," understood from a conflict perspective. Presidents of the American Sociological Association in the past twenty years have been overwhelmingly committed to some version of conflict theory. Some have self-identified as Marxists, others as feminists or critical race theorists. Meanwhile, professional associations at the regional and national levels routinely adopted as their themes the central concerns of conflict sociology, especially, power, inequality, domination, exploitation and oppression. The 2018 ASA conference focused on "racialized emotion," the 2019 conference is dedicated to "engaged scholarship for social justice," and the 2020 meeting will examine "power, inequality and resistance in the workplace."

The dialectic of the decline of the interpretive-Idealist approach and the rise of the materialist-conflict approach helps in understanding recent attacks on Constructionism and constructionists, such as the presidential address of Richard Della Buono at the national conference of the Society for the Study of Social Problems, and the sessions at that conference devoted to the theme of "beyond Constructionism." The asymmetry and hegemonic relations of the present situation become apparent when one imagines the virtual impossibility of organizing an ASA or SSSP or other professional conference around the theme, "beyond conflict theory."

When Peter Berger published a best-selling book, An Invitation to Sociology, the message was largely, "Let's build a social science together." More recently, the message has become, rather, "Let's build democratic socialism together." The accusation, a century ago, that "sociology" was simply "another name for socialism," has been virtually embraced as a badge of honor by many in the field, including the top officers of regional and national associations. Whether one regards this as desirable or not, it is arguably an important subject for sociological investigation. How did it come to be that 
"inequality" is widely regarded as the main subject of sociology, and "social justice" its disciplinary "brand"? How did there come to be such an emphasis on victims within what Bradley Campbell and Jason Manning have called a culture of victimhood?

Within this professional context, Constructionism and, one might argue, other nonconflict-centered versions of interpretive sociology such as Symbolic Interactionism, have been increasingly defined as deviant, both intellectually and ethically. Critics of these approaches, who fault them for ignoring power, domination and human suffering, and also for being disconnected from other approaches in the field, are in effect repeating Dahrendorf's call to "get out of Utopia." As the "conscience of society" (in Michael Burawoy's phrase), sociology is, for many, a movement on the left, either a civil-rights-style effort or a more radical and revolutionary struggle. If the Idealistinterpretive tradition appeals to the detached intellect, the materialist-conflict approach engages the emotions. Critical theory becomes a vocation, and sociology a call to arms. In recent decades revisionist historians have asserted that this has always been the case, at least since the period of political Progressivism and the Social Gospel in the late nineteenth and early twentieth centuries. Feminists cite the examples of Harriet Martineau, Charlotte Perkins Gilman, Jane Addams and Florence Kelly and the larger Hull House settlement circle, as well as other "women founders" discussed by Patricia Lengerman and Jill Niebrugge Brantley. Race-oriented sociologists, meanwhile, extol W. E. B. DuBois, Richard Wright and other members of the Atlanta School. From this perspective, academic sociology committed something like Original Sin around the 1920 s by becoming "scientistic" while what Mary Jo Deegan has characterized as "a dark age of patriarchy" descended, to be followed by a status-quo-oriented value neutrality epitomized in the functionalism of Talcott Parsons. Meanwhile, according to Charles Morris, Robert Park and others suppressed the work and the memory of DuBois and the Atlanta School, in order to perpetuate the white-privilege "accommodationism" championed by Booker T. Washington.

Some interpretive sociologists have recently tried to adapt to such charges by incorporating central concerns of conflict models. The 2019 meeting of the Society for the Study of Symbolic Interaction, for instance, is organized around the theme of "power, structure and intersectionality." It will be interesting to see whether such a compromise can succeed, or whether interpretive sociologists will be accused of falling short of the only true and ethical approach, which is radical critique and activism.

Meanwhile, constructionists who are deeply committed to their approach might articulate a rebuttal, based on a reading of conflict sociologies as sets of claims that can be challenged. The key ideas of conflict approaches, such as "domination" and "exploitation," are unavoidably matters of interpretation. What is regarded as exploitative by some (e.g., families, marriage, private ownership of business, religion) might also be regarded as fulfilling or empowering or even liberating by others. The notions that social problems are obvious to the naked eye, rather than constructs, or that all social problems can be reduced to the problem of inequality, are highly vulnerable. And the dominant portrait of the world as a virtual prison camp, a place of unrelieved suffering, can also be questioned. Even if every sociological critique could be proven true, people would still lead lives of value and hope, celebrate often and fall in love.

The ultimate solution that might heal current divisions and animosities is an Integral approach as advocated by Pitirim Sorokin, that would combine the insights of both the Idealist-interpretive and materialist-conflict perspectives. But will this have widespread 
appeal? The present differentiated, fragmented and polarized approaches have a powerful attraction and successful careers can be built around them.

Sociology is ultimately whatever its practitioners make it, within the constraints imposed by operative understandings of scholarship and science. The question becomes, What are the aspirations and objectives of those who choose to enter the field? The trend toward feminization has now been well documented. Does this also point toward the triumph of the materialist-conflict approach over the Idealist-interpretive perspective? Is the detached inquiry of traditional science somehow more "masculine," and "engaged scholarship for social justice" somehow more "feminine"? And if the political reigns supreme, and sociology embraces an identity as a movement on the left, how does the field fulfill its pledge of inclusiveness, in the sense of tolerance of intellectual freedom? The examination of Constructionism in this issue, it seems to me, bears upon all these large and demanding questions.

Publisher's Note Springer Nature remains neutral with regard to jurisdictional claims in published maps and institutional affiliations. 